\title{
ASSESSMENT OF ANABAENA WISCONSINENSE (CYANOPROKARYOTA) AS IMMUNOSTIMULANTS OF MALE NILE TILAPIA (OREOCHROMIS NILOTICUS)
}

\author{
Aida M. A. Dawah ${ }^{1}$, Swilem A.M. ${ }^{2}$, Zienab A. Nagdy ${ }^{1}$, Azza M. M. \\ Abd El-Rahman ${ }^{3}$ and Reham A. E. Abd - El hay ${ }^{1^{*}}$ \\ ${ }^{1}$ Limnology Dept Central Laboratory For Aquaculture Research, \\ Abbassa, Abou- Hammad, Sharkia, Egypt \\ ${ }^{2}$ Botany Dept., Faculty of Science, Benha University, Egypt \\ ${ }^{3}$ Fish Diseases Dept. Central Laboratory for Aquaculture Research, \\ Abbassa, Abu-Hammad, Sharkia. Egypt
}

\begin{abstract}
A process of assessing the effect of incorporating Cyanoprokaryota Anabaena wisconsinense on immunostimulant and enhancing fish resistance to pathogenic bacteria of Nile tilapia (Oreochromis niloticus) was conducted. One hundred and thirty five of all male O. niloticus ( $20 \pm 2 \mathrm{~g} / \mathrm{fish})$ were randomly collected from stored earthen ponds of Abbassa fish farm, Sharkia, Egypt. The fish were acclimatized for two weeks, and then divided into 3 groups (45 fish / group); each in 3 replicates containing (15 fish per / glass aquaria) supplied with 210 liters of water. The first group $\left(\mathrm{T}_{1}\right)$ was fed with basal diet (crude protein $30 \%$ ) containing $1 \%$ whole fresh cells of A. wisconsinense. The second group $\left(\mathrm{T}_{2}\right)$ was fed with the same basal diet containing $2 \%$ whole cells of $A$. wisconsinense. The third group $\left(\mathrm{T}_{3}\right)$ was fed with basal diet free from A. wisconsinense cells (control diet). Fish were hand-fed once daily in 28 days, at a rate of $3 \%$ of body weight. At the end of the feeding experiment, 90 fish were challenged (10 fish from each aquarium) with Aeromonas sabriia, Actinobacter anitratus and Aeromonas veronii and then kept under observation for 15 days. A significant increase in Haematocrit level was reported; respiratory burst and serum lysozyme activity among fish fed with diet containing (Cyanoprokaryota) compared to control fish. A. wisconsinense supplement decreased the total bacterial count in the intestine than control group and increased fish resistance to Aeromonas sabriia, Actinobacter anitratus and Aeromonas veronii.
\end{abstract}

\section{Introduction}

Cyanoprokaryota have been identified as one of the most promising group of organisms from which novel and biochemically active natural products are isolated. Cyanoprokaryota such as Microcystis, Anabaena, Nostoc and Oscillatoria produce a great variety of secondary metabolites. Cyanoprokaryota produce a wide variety of toxins and other bioactive compounds, which include 40\% lipopeptides, 5.6\% amino acids, $4.2 \%$ fatty acids, $4.2 \%$ macrolides and $9 \%$

* Corresponding author: E.mail: reham4ever1@yahoo.com

(ISSN: 1110-8649) 
amides. Cyanoprokaryotal lipopeptides include different compounds like cytotoxic (41\%), antitumor (13\%), antiviral (4\%), antibiotics $(12 \%)$ and the remaining $18 \%$ activities containing antimalarial, antimycotics, multidrugresistance-reversers, herbicides and immunosuppressive agents (Burja et al., 2001); besides the immune effect, blue green algae improves metabolism. Fish disease, especially bacterial infections, is a major problem facing the fish farming industry, which is currently growing fast with an annual increase of approximately $12 \%$ (FAO, 2004). Treatment with antibiotics and chemotherapeutics continues to be one of the important disease control measures in aquaculture industry (Amábile-Cuevas et al., 1995). The use of antibiotics in aquaculture may pose potential hazard to public health and to the environment by the emergence of drug-resistant microorganisms and antibiotic residues. Furthermore, the normal microbial flora in the digestive tract, which is beneficial to fish, is also killed or inhibited by oral chemotherapy (Sugita et al., 1991). Nile tilapia, Oreochromis niloticus (L.) is one of the important freshwater aquaculture species. Consumers like tilapia's firm flesh and mild flavor to the extent that its markets have expanded rapidly (FAO, 2005) and the improvement of its culture and diseaseresistance is a major challenge facing fish culturists. Some cyanoprokaryotal species could be a prolific resource for substances with antibacterial activity. Metabolites of some species of cyanoprokaryota are providing potential leads for the development of new pharmaceutical compounds. Therefore, the present study mainly aims at investigating the immunostimulant effect of $A$. wisconsinense on Nile tilapia (Oreochromis niloticus) so as to produce fish that are more resistant to bacterial diseases and free of antibiotics residues. Whereas, the use of algae as antibacterial creates pollution free environment and minimizes potential hazard to public health. When this issue is better understood, Cyanoprokaryota might become economic sources of new drugs because production can be optimized in controlled culture.

\section{Materials and Methods}

\section{The isolated blue green alga:}

The blue green alga (Cyanoprokaryota) used in this study was Anabaena wisconsinense which was isolated and identified in a previous published study (Abdel-Wahab, 2007).

Evaluation of blue-green algae as growth promoters, immunostimulant and enhancing fish resistant against pathogenic bacteria:

\section{Cultivation of $A$. wisconsinense:}

A. wisconsinense was cultivated in BG11 medium. The culture was incubated at $30 \pm 2{ }^{\circ} \mathrm{C}$ under continuous illumination produced by white fluorescent light (3000-5000 lux). Alga was harvested at the late exponential growth phase. 


\section{Feed preparation:}

Commercial basal diet (crude protein $30 \%$ ) was crushed, and then divided into three parts. The first part was mixed with $(1 \%)$ whole cells of living $A$. wisconsinense. The second part was mixed with $(2 \%)$ whole cells of living $A$. wisconsinense. The third part was mixed with the BG11 medium free from algae (control group). The diet was reformed into pellets, spread to air dry and stored at $4^{\circ} \mathrm{C}$ for the feeding experiment.

\section{Feeding experiment:}

One hundred and thirty five of all male $O$. niloticus ( $20 \pm 2 \mathrm{~g} /$ fish) were randomly collected from the stored earthen ponds of Abbassa Fish Farms, AbouHammad, Sharkia. The fish were acclimatized for two weeks, divided in nine glass aquaria (210 1/aquaria) and supplied with continuous aeration using air pumping compressors. Fish were allocated into 3 groups (45 fish / group); each in three replicates (15 fish / glass aquaria). The compositions of feeds were the following:

- Group $1\left(\mathrm{~T}_{1}\right)$ : Basal diet containing $1 \%$ whole cells of $A$. wisconsinense.

- Group $2\left(\mathrm{~T}_{2}\right)$ : Basal diet containing $2 \%$ whole cells of $A$. wisconsinense.

- Group $3\left(\mathrm{~T}_{3}\right)$ : Control (The basal diet free from A. wisconsinense).

Fish were hand-fed once daily in 28 days, at a rate of $3 \%$ of body weight. The water aquaria were siphoned daily. The fish were weighed at day $7,14,21$ and 28 since the start of the experiment.

\section{Blood and serum sample for immunity assay:}

In the second week and the fourth week of the feeding experiment, the fish were anaesthetized by immersing the fish in water containing $0.1 \mathrm{ppm}$ tricaine methane sulphonate (MS-222). Blood-samples were collected from the caudal vein of fish, by using needles previously rinsed in heparin ( 15 unit $/ \mathrm{ml}$ ) for the evaluation of haematocrit and respiratory burst activity. For plasma separation, the heparinzed blood was centrifuged at $3000 \mathrm{rpm}$ for 5 minutes. The plasma was stored at $-20^{\circ} \mathrm{C}$ in screw cap glass vials until used for lysozyme.

\section{Haematocrit level:}

Haematocrit level is a method used to determine the volume of packed cells in the blood. The haematocrit value will vary depending on the health and the physiological condition of the individual fish. Haematocrit capillary tubes are filled $2 / 3$ with whole blood, tube were centrifuged in haematocrit centrifuge for 5 minutes. After centrifugation, the percentage of erythrocyte volume is measured by haematocrit tube reader. 


\section{Respiratory burst activity by measuring Nitro Blue Titrazolium activity (NBT):}

The NBT (yellow) is reduced to formazan (blue) in the reaction with oxygen radicals from neutrophils and monocytes. The production of oxygen radicals analyzed using NBT can be done by spectrophotometer.

$0.1 \mathrm{ml}$ of blood was placed into microtiter plate, then an amount equal to $0.2 \%$ NBT solution was added and incubated for 30 minutes at room temperature. $0.1 \mathrm{ml}$ of NBT blood cell suspension was taken and added to a glass tube containing $1 \mathrm{ml} \mathrm{N}, \mathrm{N}$ - dimethylformamide and centrifuged for 5 minutes at 3000 rpm. The supernatant fluid was read in spectrophotometer at $620 \mathrm{~nm}$ in $1 \mathrm{ml}$ cuvettes (Siwicki et al., 1985).

\section{Serum Lysozyme activity:}

The lysozyme activity was measured using photoelectric colorimeter with attachment for turbidity measurement. A series of dilution was prepared by diluting the standard lysozyme from hen egg-white (Fluka, Switzerland) and mixed with Micrococcus lysodeikticus (ATCC No. 1698 Sigma) suspension for establishing the calibration curve. $10 \mathrm{ml}$ of standard solution or serum were added to $200 \mathrm{ml}$ suspension of Micrococcus (35 $\mathrm{mg}$ of Micrococcus dry powder/95 ml of $1 / 15 \mathrm{M}$ phosphate buffer $5.0 \mathrm{ml}$ of $\mathrm{NaCl}$ solution).The changes in the extinction were measured at $546 \mathrm{~nm}$ through measuring the extinction immediately after adding the solution containing the lysozyme (start of the reaction). After 20 mins, incubation of the preparation was under investigated at $40^{\circ} \mathrm{C}$ (end of the reaction). The lysozyme content is determined depending on the basis of the calibration curve and the extinction measured (Schaperclaus et al., 1992).

\section{Total Bacterial Counts in fish intestine (TBC):}

Three fish samples from each replicate were collected randomly; under complete aseptic condition, the fish samples were dissected, weighed (1g) of intestine, placed in sterile mortar containing $9 \mathrm{ml}$ of peptone water, and gently homogenized in a rotating motion for ten minutes. The mixture was filtered through sterile filter paper. $1 \mathrm{ml}$, placed in each plate, 3 plates were used for each sample of fish. In each plate triptic soya agar medium was poured and the plates were subsequently rotated in a different direction to ensure complete distribution of the inoculums within the media. After solidification, the inoculated plates were incubated at $25^{\circ} \mathrm{C}$ for $24-48$ hours. The colonies were counted after the incubation period according to Austin and Austin (1993).

\section{Challenge test:}

At the end of the feeding experiment, the fish of each group were divided into three subgroups (distributed in 3 aquaria). The fish were challenged intraperitoneally (i.p.) with $0.5 \mathrm{ml} 10^{7}$ cells of $24 \mathrm{~h}$ cultures of live Aeromonas sabriia, Actinobacter anitratus and Aeromonas veronii. The challenged fish were 
kept under observation for 15 days. The moribund fish were used for bacterial reisolation while the mortalities were recorded. The relative level of protection (RLP) among the challenged fish was determined according the following question:

RLP $=1$ - [percentage of treated mortality/ percentage of control mortality] x100.

\section{Statistical analysis:}

Statistical analysis was performed using the one way analysis of variance (ANOVA). It was performed with SPSS statistical software (version 10.0, SPSS). The data were subjected for test of homogeneity of variances and Duncan test and were considered significantly different when $\mathrm{P} \leq 0.05$.

\section{Results}

\section{Haematocrit Value:}

From Table (1), the haematocrit values ranged from $18.3 \pm 0.88$ to $21.3 \pm$ $0.88 \%$ among the three treatments in the second week of feeding $A$. wisconsinense with supplemented diet. The haematocrit value increased significantly in the fourth week of feeding with $T_{1}$ and $T_{2}$ than $T_{3}$. Haematocrit value was high in $\mathrm{T}_{1}$ than $\mathrm{T}_{2}$ in $2^{\text {nd }}$ and $4^{\text {th }}$ week.

Table (1): The effect of Anabaena wisconsinense supplemented diet on Haematocrit (HCV), respiratory burst (NBT) and serum lysozyme activity in Oreochromis niloticus feeding for 28 days.

\begin{tabular}{|c|c|c|c|c|c|c|}
\hline \multirow{2}{*}{ Treatments } & \multicolumn{2}{|c|}{ HCV $(\boldsymbol{\%})$} & \multicolumn{2}{c|}{ NBT $(\mathbf{m g} / \mathbf{m l})$} & \multicolumn{2}{c|}{ Lysozyme Activity $(\boldsymbol{\mu g} / \mathbf{m l})$} \\
\cline { 2 - 7 } & $\mathbf{2}^{\text {nd }}$ Week & $\mathbf{4}^{\text {th }}$ Week & $\mathbf{2}^{\text {nd }}$ Week & $\mathbf{4}^{\text {th }}$ Week & $\mathbf{2}^{\text {nd }} \mathbf{W e e k}^{\mathrm{a}}$ & $\mathbf{4}^{\text {th }} \mathbf{W e e k}^{\mathrm{a}}$ \\
\hline T1 & $21.3 \pm 0.88^{\mathrm{a}}$ & $66.0 \pm 3.05^{\mathrm{a}}$ & $1.745 \pm 0.07^{\mathrm{a}}$ & $1.861 \pm 0.04^{\mathrm{a}}$ & $1.964 \pm 0.02^{\mathrm{a}}$ & $2.291 \pm 0.23^{\mathrm{a}}$ \\
\hline T2 & $18.3 \pm 0.88^{\mathrm{a}}$ & $49.3 \pm 2.33^{\mathrm{b}}$ & $1.339 \pm 0.12^{\mathrm{b}}$ & $1.466 \pm 0.05^{\mathrm{a}}$ & $1.084 \pm 0.38^{\mathrm{b}}$ & $1.960 \pm 0.10^{\mathrm{a}}$ \\
\hline T3 & $21.0 \pm 3.6^{\mathrm{a}}$ & $21.0 \pm 2.08^{\mathrm{c}}$ & $1.396 \pm 0.07^{\mathrm{b}}$ & $1.396 \pm 0.07^{\mathrm{a}}$ & $2.018 \pm 0.12^{\mathrm{a}}$ & $2.018 \pm 0.12^{\mathrm{a}}$ \\
\hline
\end{tabular}

\section{Respiratory burst activity:}

The results from Table (1) showed that the value of NBT in $\mathrm{T}_{1}(1.745 \pm$ $0.07)$ was significantly higher than the value in $T_{2}(1.339 \pm 0.12)$ in the $2^{\text {nd }}$ week of feeding A. wisconsinense with supplemented diet. In the fourth week of feeding experiment, NBT assay was slightly increased to $1.861 \pm 0.04$ and $1.466 \pm 0.05$ $\mathrm{mg} / \mathrm{ml}$ in both $\mathrm{T}_{1}$ and $\mathrm{T}_{2}$ respectively, while the control group had no changes. Generally, $T_{1}$ had respiratory burst higher than $T_{2}$ in the $2^{\text {nd }}$ and $4^{\text {th }}$ week of feeding experiment.

\section{Serum Lysozyme activity:}

The results in Table (1) indicated that there was no significant difference between the lysozyme activity in $\mathrm{T}_{3}(2.018 \pm 0.12 \mu \mathrm{g} / \mathrm{ml})$ and $\mathrm{T}_{1}(1.964 \pm 0.02 \mu \mathrm{g}$ $/ \mathrm{ml})$ in the $2^{\text {nd }}$ week. In the $4^{\text {th }}$ week of feeding experiment, the lysozyme activity increased in $\mathrm{T}_{1}$ and $\mathrm{T}_{2}$ to $2.291 \pm 0.23$ and $1.960 \pm 0.10 \mu \mathrm{g} / \mathrm{ml}$ respectively. The 
increasing in lysozyme activity in $T_{2}$ in the period starting from the $2^{\text {nd }}$ to the $4^{\text {th }}$ week was higher than the increase in $T_{1}$ or $T_{3}$ (control) of feeding experiment.

\section{Total bacterial count of fish intestine:}

Data in Table (2) indicates that the total bacterial count of $O$. niloticus intestine in the $2^{\text {nd }}$ week of feeding were $160.33 \pm 3.17,140.00 \pm 5.7$ and $163.33 \pm 7.7$ $\mathrm{cfu} / \mathrm{g}$ in $\mathrm{T}_{1}, \mathrm{~T}_{2}$ and $\mathrm{T}_{3}$ respectively. It also indicates that the total bacterial count decreased sharply in the $4^{\text {th }}$ week to be $20.33 \pm 3.17$ and $57.66 \pm 5.2 \mathrm{cfu} / \mathrm{g}$ at $\mathrm{T}_{1}$ and $\mathrm{T}_{2}$, with no change in $\mathrm{T}_{3}$.

Table (2): Total bacterial counts (TBC) in Oreochromis niloticus intestine after feeding with diet contained 1 and $2 \%$ whole cell of Anabaena wisconsinense in $2^{\text {nd }}$ and $4^{\text {th }}$ week compared to diet without cells.

\begin{tabular}{|c|c|c|}
\hline \multirow{2}{*}{ Treatments } & \multicolumn{2}{|c|}{ Total Bacterial Counts in Fish Intestine (TBC) } \\
\cline { 2 - 3 } & $2^{\text {nd }}$ Week & $\mathbf{4}^{\text {th }}$ Week $^{\mathbf{c}}$ \\
\hline T1 & $160.33 \pm 3.17^{\mathbf{a b}}$ & $20.33 \pm 3.17^{\mathbf{c}}$ \\
\hline $\mathbf{T 2}$ & $140.00 \pm 5.7^{\mathbf{b}}$ & $57.66 \pm 5.2^{\mathbf{b}}$ \\
\hline $\mathbf{T 3}$ (control) & $163.33 \pm 7.7^{\mathbf{a}}$ & $163.33 \pm 7.7^{\mathbf{a}}$ \\
\hline
\end{tabular}

\section{Challenge test:}

\section{Challenged with:}

\section{A. Aeromonas veronii:}

Figure (1) illustrates that $O$. niloticus challenged with pathogenic Aeromonas veronii had higher mortality in $\mathrm{T}_{3}(40 \%)$ than the other treatments that received Anabaena wisconsinense supplemented diet. The mortality rates were 0.0 and $10 \%$ in $\mathrm{T}_{1}$ and $\mathrm{T}_{2}$ respectively. In Figure (2), relative level of protection against Aeromonas veronii in $\mathrm{T}_{1}$ was higher than in other treatments $(100 \%)$ and decreased in $\mathrm{T}_{2}$ to $75 \%$.

\section{B. Aeromonas sobria:}

Figure (1) indicates that $O$. niloticus challenged with pathogenic A. sobria had higher mortality in $\mathrm{T}_{3}(40 \%)$ than the other treatments that received the $A$. wisconsinense supplemented diet. The mortality rates were (20 and 10\%) at $\mathrm{T}_{1}$ and $\mathrm{T}_{2}$ respectively. In Figure (2), relative level of protection against $A$. sobria in $\mathrm{T}_{2}$ was higher than in other treatments $(75 \%)$ and decreased in $\mathrm{T}_{1}$ to $50 \%$.

\section{Actinobacter anitratus:}

Figure (1) indicates that $O$. niloticus challenged with pathogenic Actinobacter anitratus had higher mortality in $\mathrm{T}_{3}(30 \%)$ than other treatments that received the Anabaena wisconsinense supplemented diet. The mortality rates were (20 and 20\%) in $\mathrm{T}_{1}$ and $\mathrm{T}_{2}$ respectively. In Figure (2), relative level of protection against Actinobacter anitratus in $\mathrm{T}_{1}$ and $\mathrm{T}_{2}$ was $(50 \%)$. The fish injected by saline 
and divided in three groups had no mortality and had (100\%) as relative level of protection.

Figure (1): Mortality rate of Oreochromis niloticus fed with diet containing whole cell

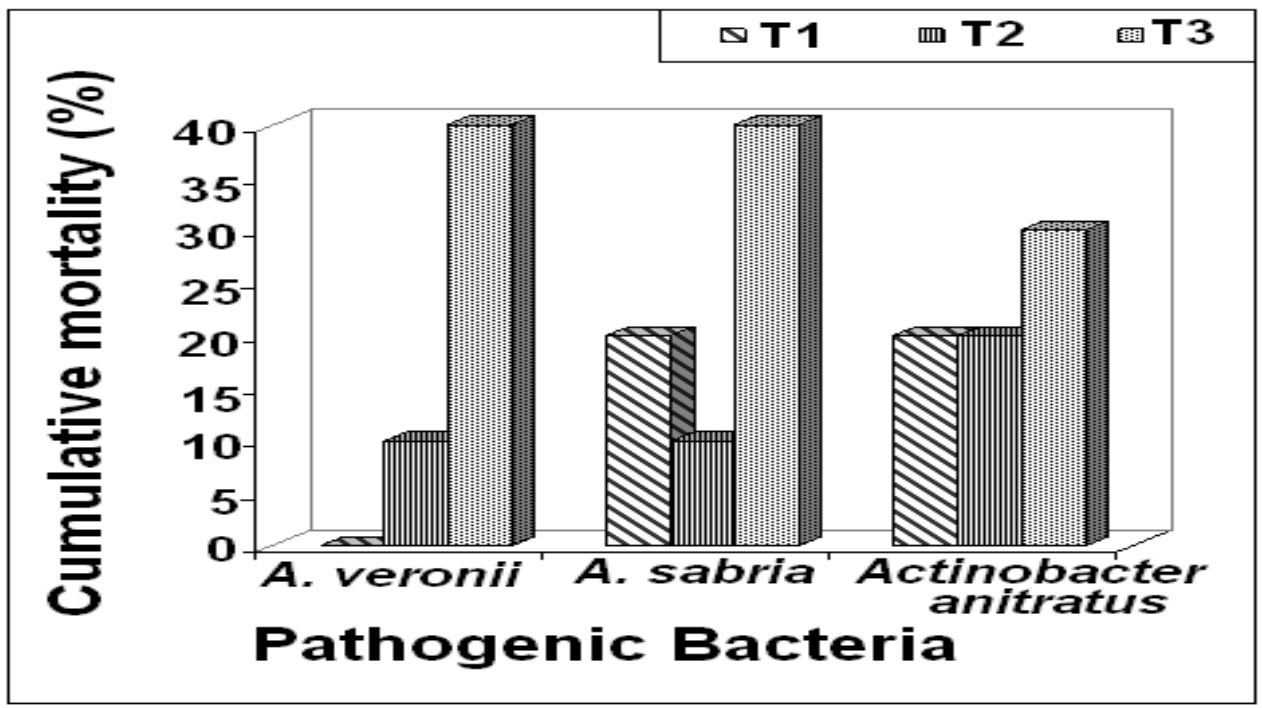

of Anabaena wisconsinense for four weeks compared to (control) without cells and experimentally infected with $A$. veronii, $A$. sobria and Actinobacter anitratus and were kept under observation for 15 days.

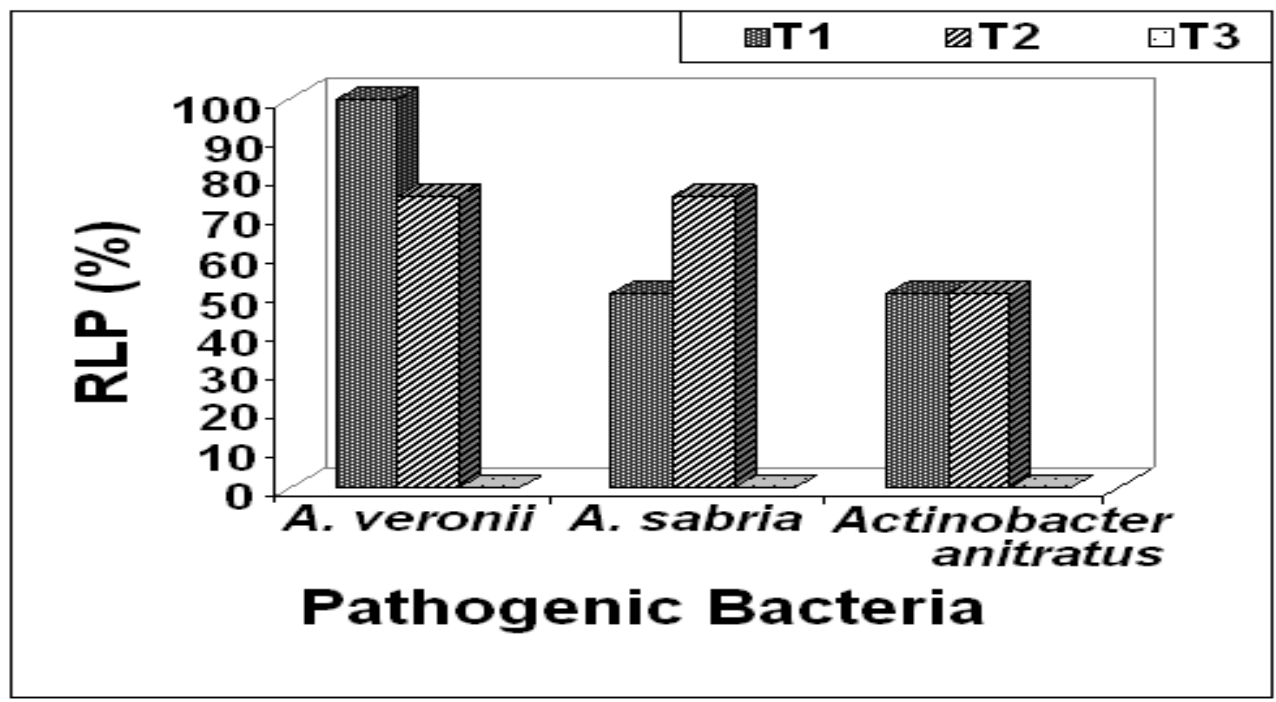

Figure (2): Relative level of protection in Oreochromis niloticus fed with Anabaena wisconsinense supplemented diet for 28 days and challenged i.p. with $0.5 \mathrm{ml} \times 10^{7}$ cells of $A$. veronii, A. sobria and Actinobacter anitratus. 


\section{Discussion}

Cyanoprokaryota are a natural component of the diet for many fish species (Dempster et al., 1993; Figuerdo and Giani, 2005) and are often included in aquafeeds (FAO, 2008).

Our research shows that Oreochromis niloticus fed with (1 and $2 \%)$ live cell of $A$. wisconsinense with the supplemented diet $\left(\mathrm{T}_{1}\right.$ and $\left.\mathrm{T}_{2}\right)$; while $\mathrm{T}_{3}$ is a fish group fed with diet free from $A$. wisconsinense.

In the fourth week of feeding experiment, A. wisconsinense supplemented diet enhanced haematocrit value and serum lysozyme activity. Merrifield $\boldsymbol{e t}$ al. (2010) found that $0.5 \%$ and $1.0 \%$ Chlorogloeopsis (Cyanoprokaryota) groups supplemented diet increased Haematocrit levels and serum lysozyme activity of red tilapia (Oreochromis niloticus) compared to the control group.

Also A.wisconsinense supplemented diet enhanced NBT activity. Increased respiratory burst activity can be correlated with increased bacterial pathogen killing activity of phagocytes (Sharp and Secombes, 1993). The respiratory burst activity of phagocytes was measured by reduction of NBT by intracellular superoxide radicals produced by leucocytes. Similar findings were reported by Andrews $\boldsymbol{e t}$ al. (2011) who observed that the fed by 1,2\% concentration of Spirulina sp. increased phagocytic activity in Labeo rohita fingerlings. Abdo et al. (2010) reported that Anabaena species contain carotenes and phycocyanin which enhance immune system, while carotenes act as vitamin A activity, antioxidants and phycocyanin act as antioxidant and anticancer.

In this study the tilapia fed with $1 \%$ A. wisconsinense supplemented diet had the best effect on total bacterial of fish intestine. Algae are rapidly proving to be an extremely important source of biologically active secondary metabolites which could be used for the biological control of pathogens. Cyanoprokaryota are one of the most sources of biomedical relevant compounds with extensive (Gademann and Portmann, 2008; Martins et al., 2008). Anabaena spp produce a number of bioactive compounds, mostly lipopeptidases that have antibiotic, antialgal, anticancer, anti-inflammatory, cytotoxic and enzyme-inhibiting effects (Fujii et al., 2002). The antibiotic activities exhibited by different cyanoprokaryota were bioactive compounds as Hapalindoles alkaloids or Cyanobacterin. The saturated fatty acids; caprylic, capric, lauric, myrestic and the un-saturated ones; palmitaleic, leic, linoleic and linolenic acids were demonstrated to have antimicrobial activities (Shanab, 2007). A. flos aquae, produce heptadecane which have antimicrobial activity (Khairy and El-Kassas, 2010). In a study similar to these, there was a significant decrease in total bacterial count of fish intestine fed with A. wisconsinense supplemented diet compared to control one in the second and fourth week of feeding experiment.

It is important to estimate the relative level of protection in the treated fish to determine the efficiency of an immunostimulant. The relative level of protection (\%) after challenging with Aeromonas veronii, Aeromonas sobria and 
Actinobacter anitratus indicates that $A$. wisconsinense supplementation diet (immunostimulant) had a positive influence on the relative level of protection with (Oreochromis niloticus) through increasing fish resistance to the infection. The Cyanoprokaryota diet groups reduce mortality induced by pathogenic bacteria when compared to the control group. The reduction of mortalities occurred in groups treated with $A$. wisconsinense due to the increase of lysozyme and NBT activities. Lysozyme had inhibitory effect on bacteria in blood. Also, NBT gave an indication to increasing radical oxygen having bacterial inhibition effect as well. Similar to our results, Abdel - Tawwab and Ahmed (2009) secured mortality decrease of Oreochromis niloticus, injected with pathogenic Aeromonas hydrophila after the increase of the Spirulina level in tilapia fish diets.

\section{Conclusion}

The present study concluded that A. wisconsinense increased immuno boosting ability and resistance to Aeromonas veronii, Aeromonas sobria and Actinobacter anitratus infection of Nile tilapia. It is important that future studies assess the effect of Cyanoprokaryota as immunostimulants the innate immunity of fish.

This study was carried in Central Laboratory for Aquaculture Research at Abbassa, Agriculture Research Center, Ministry of Agriculture, Egypt.

\section{References}

Abdel-Wahab, R. (2007). Antimicrobial Activity of Some Phyto Plankton Isolates From Aquatic Ecosystem of Abbassa-Sharkia. Msc. thesis. Fac. of Sci., Benha Uni., Egypt.

Abdel-Tawwab, M. and Ahmad, M.H., (2009). Live Spirulina (Arthrospira platensis) as a growth and immunity promoter for Nile tilapia, Oreochromis niloticus (L.), challenged with pathogenic Aeromonas hydrophila. Aquacult. Res., 40: 1037-1046.

Abdo, Sayeda M.; Hetta, Mona H.; Salah El Din, Rawheya A. and Ali, Gamila H. (2010). Growth Evaluation and Bioproduct Characteristics of Certain Freshwater Algae Isolated from River Nile, Egypt. J. of Appli. Sci. Res., 6(6): 642-652.

Amábile-Cuevas, C. F.; Gardenas-Garcia, M. and Ludgar, M. (1995). Antibiotic resistance. Am. Sci., 83: 320-329.

Andrews, S. R.; Sahu, N. P.; Pal, A. K.; Mukherjee, S.C. and Kumar, S. (2011). Yeast extract, brewer's yeast and spirulina in diets for Labeo rohita fingerlings affect haemato-immunological responses and survival following Aeromonas hydrophila challenge. Res. in Vet. Sci., 91:103-109.

Austin, B. and Austin, D. A. (1993). Bacterial fish pathogens: Diseases in farmed and wild fish. 2nd ed. Ellis Horwood Ltd., Chichester, England. $364 p p$. 
Burja, A. M.; Banaigs, B.; Abou-Mansour, E.; Grant Burgess, J. and Wright, P. C. (2001). Marine Cyanoprokaryota-a prolific source of natural products. Tetrahedron, 57(46): 9347-9377.

Dempster, P. W.; Beveridge, M. C. M. and Baird, D. J. (1993). Herbivory in the tilapia Oreochromis niloticus: a comparison of feeding rates on phytoplankton and periphyton. J. Fish Biol., 43:385-392.

FAO (Food and Agriculture Organization) (2004). The state of world fisheries and Aquaculture. Rome, Italy, 14-17.

FAO (Food and Agriculture Organization) (2005). Yearbook of Fisheries Statistics extracted with Fish State Version 2.30 (Copyright 2000). Fisheries database: Aquaculture production quantities 1950-2003; aquaculture production values 1984-2003; capture production 1960-2003; Commodities Production and Trade 1976-2002.

FAO (Food and Agriculture Organization) (2008). A review of culture, production and use of Spirulina as food for humans and feeds for domestic animals and fish. Fish. and Aqua. Cir., No. 1034.

Figuerdo, C. C. and Giani, A. (2005). Ecological interactions between Nile tilapia (Oreochromis niloticus, L.) and the phytoplanktonic community of the Furnas Reservoir (Brazil). Fresh w. Biol., 50:1391-1403.

Fujii, T.; Nakao, F.; Shibata, Y.; Shioi, G.; Kodama, E.; Fujisawa, H.; Takagi, S. (2002). Caenorhabditis elegans PlexinA, PLX-1, interacts with trans membrane semaphorins and regulates epidermal morphogenesis. Devel., 129: 2053-2063.

Gademann, K. and Portmann, C. (2008). Secondary metabolites from cyanoprokaryota: complex structures and powerful bioactivities. Curr. Org. Chem., 12: 326-341.

Khairy; Hanan, M. and El-Kassas, Hala Y. (2010). Active substance from some blue green algal species used as antimicrobial agents. Afri. J. of Biotechno., 9(19): 2789-2800.

Martins, R. F.; Ramos, M. F.; Herfindal, L.; Sousa, J. A.; Skærven, K. and Vasconcelos, V. T. (2008). Antimicrobial and cytotoxic assessment of marine cyanoprokaryota Synechocystis and Synechococcus. Mar. Drugs, 6: 1-11.

Merrifield, D. L.; Güroy, D.; Güroy, B.; Emery, M. J.; Llewellyn, C. A.; Skill, S. and Davies, S. J. (2010). Assessment of Chlorogloeopsis as a novel microbial dietary supplement for red tilapia (Oreochromis niloticus). Aquacult., 299: 128-133.

Shanab, Sanaa M M. (2007). Bioactive Allelo-chemical Compounds from Oscillatoria Species (Egyptian Isolates). Int. J. of Agricul. and Biol., 9: 4.

Sharp, G. J. E. and Secombes, C. J. (1993). The role of reactive oxygen species in the killing of the bacterial fish pathogen Aeromonas salmonicida by rainbow trout macrophages. Fish and Shellfish Immuno., 3: 119-129.

Schaperclaus, W.; Kulow, H. and Schreckenbach, K. (1992). Fish disease. Rotterdam, the Netherlands: A. A. Balkema; 101-105.

Egyptian J. of Phycol. Vol. 12, $2011 \quad$ - 10 - 
Siwicki, A. K.; Studnicka, M. and Ryka, B. (1985). Phagocytic ability of neutrophils in carp. Bamidgeh, 37: 123-128.

Sugita, H.; Miyajima, C. and Deguchi Y. (1991). The vitamin $B_{12^{-}}$producing ability of the intestinal microflora of freshwater fish. Aquaculture, 92: 267-276.

\section{تقييم تأثثير أضافة أنابينا وسكونينسينس-كبروبيوتك (سيانوغيرحقيقى النواة) فى التغذية على المناعة فى ذكور البلطى النيلى \\ عايدة محمد عبدالله ضوة", محمود عبدالمحسن سويلم²زينب عطية النجدى1، عزة محمد محمد عبدالرحمن3

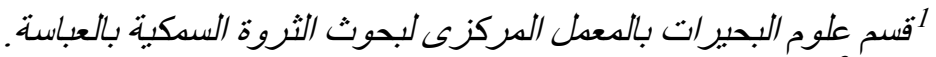

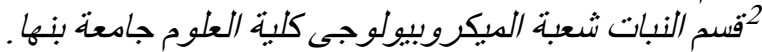

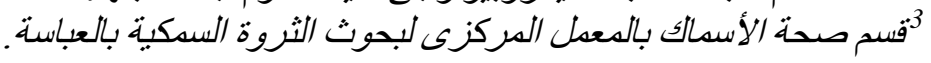

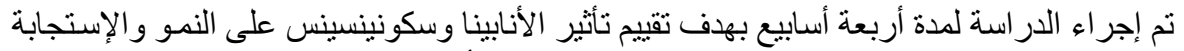

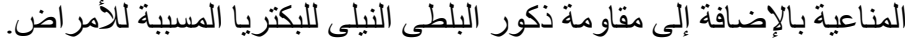

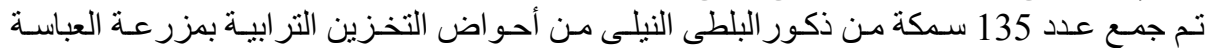

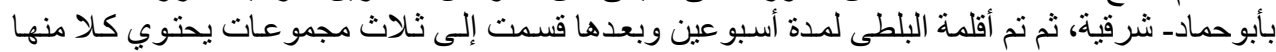

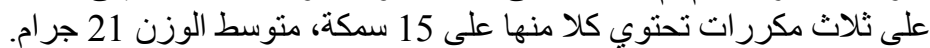

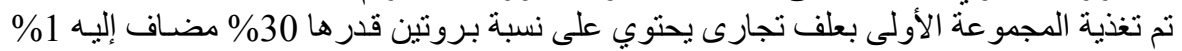

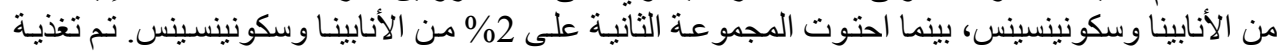

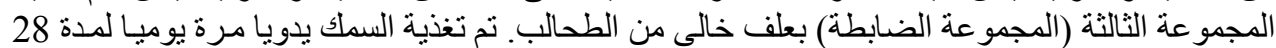

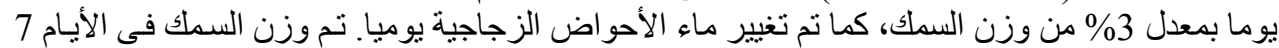

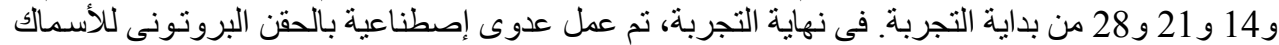

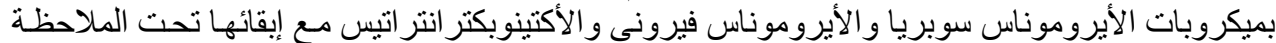

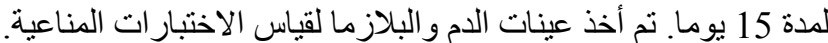

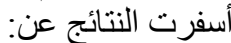

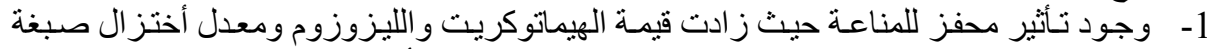

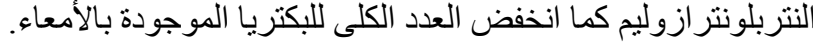

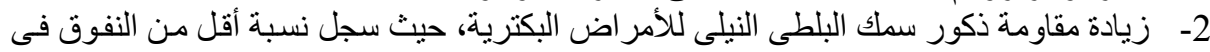
المجموعات المغذاة على الطحلب مقارنة بالمجموعة الضابطة الطئ.
} 